\title{
Europe's Got Talent: Setting the Stage for New Teachers by Educative Mentoring
}

KARIN DA ROCHA ${ }^{1}$

$\approx$ Growing challenges, demographic change and the need to deal with various demands in one's professional and private life call for a high flexibility and willingness to learn, especially among teachers, who serve as role models in this respect. Consequently, professional development has to focus on reflective and introspective processes. At the beginning of a teaching career, educative mentoring can provide valuable support. In the course of planning a new teacher-training program in Austria, the University College of Teacher Education Styria, in Graz, is conducting a mentoring project in primary schools from 2012 to 2014. It takes place in two Styrian districts and is accompanied by evaluation research. Local mentors support new teachers. Moreover, in-service training for new teachers, mentors and principals is provided. The topics of the courses correspond to the participant groups' roles and interests, foster social and digital networking, and encourage peer discussion and cross-group communication. The qualitative research entailed in the project investigates supporting factors of educative mentoring and communication processes by applying questionnaires, expert interviews and group discussions. This article focuses on the role, challenges and duties of a mentor, taking into account the value of educative mentoring for professional learning communities and individual learning processes.

Keywords: teachers' competence, educative mentoring, induction, mentor, new teachers 


\section{Evropa ima talent: vpeljevanje novih učiteljev s pomočjo mentorstva}

KARIN DA Rocha

$\approx$ Vedno večji izzivi, demografske spremembe in potreba po spopadanju $\mathrm{Z}$ različnimi zahtevami v posameznikovem profesionalnem in osebnem življenju zahtevajo večjo prilagodljivost in pripravljenost za učenje. To še posebej velja za učitelje, ki so v teh pogledih vzorniki drugim. Zato mora profesionalni razvoj temeljiti na reflektivnih in samoopazovalnih procesih. Na začetku učiteljeve kariere lahko izobraževalno mentorstvo nudi pomembno podporo. $\mathrm{V}$ okviru načrtovanja novega programa za izobraževanje učiteljev v Avstriji je pedagoška visoka šola v Gradcu med letoma 2012 in 2014 izvajala projekt mentorstva v osnovnih šolah. Ta je potekal v dveh štajerskih okrožjih, spremljala pa ga evalvacijska raziskava. Krajevni mentorji nudijo podporo novim učiteljem. Poleg tega je organizirano tudi strokovno izpopolnjevanje za nove učitelje, mentorje in za ravnatelje. Teme izobraževanj odražajo vloge in interese posameznih skupin, nudi se socialno in digitalno mreženje, spodbujata se medsebojno diskutiranje in interakcija med skupinami. S pomočjo kvalitativne raziskave prek vprašalnikov, intervjujev in fokusnih skupin so bili v projektu analizirani faktorji podpore pri izobraževalnem mentorstvu in komunikacijskih procesih. V prispevku se osredinjamo na vlogo, izzive in na naloge mentorja $\mathrm{z}$ vidika pomena, ki ga ima izobraževalno mentorstvo za strokovno učečo se skupnost in individualne učne procese.

Ključne besede: kompetence učiteljev, izobraževalno mentorstvo, pripravništvo, mentor, novi učitelji 


\section{Introduction}

The induction of new teachers to their profession is currently used and evaluated in various countries worldwide. It is also a focus of interest in Austrian pedagogic research for two reasons. Because several hundred primary and secondary teachers are going to retire in the next few years, many new teachers are going to start their careers. They are often deprived of their elder colleagues' experiential knowledge if there are no transfer phases for intergenerational communication. Thus far, new teachers in Austrian primary and compulsory secondary schools are not accompanied by mentors at their local schools, although the amount of teaching practice is high during pre-service training. The new curriculum allots a four-year bachelor studies program, an obligatory induction period supported by mentors at school and a subsequent two-year master studies program.

This article focuses on mentors' challenging duties, taking a short look at existing European practices within this field. Moreover, this position's demanding profile is related to national and regional requirements aimed at induction as a part of the new Austrian teacher-training program. These findings are based on the project Supporting New Teachers at the Beginning of their Professional Careers, which is being carried out by the University College of Teacher Education Styria from 2012 to 2014. Finally, the relations between European, national and regional aspects in mentoring are discussed.

\section{Setting the stage for new teachers: educative mentoring in induction}

In their pre-service trainings, the amount of teaching practice for European pedagogical students varies considerably. Moreover, there are school and teaching-related situations that cannot be simulated, such as organizational issues or parent-teacher meetings. As Feiman-Nemser states, "[...] beginning teachers have legitimate learning needs that cannot be grasped in advance or outside the context of teaching" (Feimann-Nemser, 2003, p. 26). Terhart (2001) and Hericks (2006) both assert that new teachers need to develop professional attitudes and coping strategies for dealing with unfamiliar situations. Here, Helsper $(1996,2012)$ refers to typical antinomies such as the uniformity and deviation as well as the distance and proximity new teachers have to deal with at the beginning of their careers. Accordingly, models about new teachers' school entrance talk about terms, such as surviving, exploring and mastering (Fuller \& Brown, 1975; Hubermann, 1991). In order to do so, it is of great value if new 
teachers are provided with necessary resources, including time with a mentor for guided reflection or professional conversation.

With a focus on co-operative relationship-based professional communication, educative mentoring offers a rather formal setting, employing an expert from the field of work (Ittel \& Raufelder, 2009). It is characterized by "cultivating a disposition of inquiry, focusing attention on student thinking and understanding, and fostering disciplined talk about problems of practice" (Feimann-Nemser, 2001, p. 28). The model aims to induce lifelong personal and professional learning processes by co-operative, reciprocal learning. In this respect, the mentor's willingness to agree to mutual learning is of the utmost importance. Otherwise, the concept does not go beyond a typical "apprenticeship model" (Halai, 2006).

Therefore, it must be kept in mind that the mentors to also need to be prepared for the new role they are going to take on. Self-reflection, an active interest in their own professional development, interest in and tolerance for colleagues' opinions and co-operation are preconditions for successful mentoring (Langdon, 2007). In addition to knowledge about the educative mentoring model, mentors need to be familiar with communicative tools for critical feedback and supportive reflection processes.

From a more general perspective, referring mainly to building a professional attitude, it is necessary to embed mentoring in more far-ranging principles to foster personal learning. Gardner (2009) provides five guidelines that can serve for such a purpose:

- the Disciplined Mind, which refers to dealing in-depth with an area of expertise,

- the Synthesizing Mind, which describes the selection and connection of ideas from different fields of experience,

- the Creating Mind, which comprises combining a person's excellence in a field with posing new challenging questions and discussing solutions from various perspectives,

- the Respectful Mind, which means tolerance towards heterogeneity in people and accepting them, and

- the Ethical Mind, which focuses on taking on societal responsibility.

This short overview highlights the value of Gardner's concept for a broader view on learning, which can serve as a guideline not only for mentoring but for learning in general. How the learning-through-mentoring concepts varies in different countries is described below. 


\section{International experience and national needs}

Both induction programs and educative mentoring as an effective means have been tested and endorsed worldwide (Wang \& Odell, 2007; Blömeke \& Paine, 2009). Experiences include, for example, expert knowledge from AngloAmerican countries (Great Britain, the United States, Australia and New Zealand) as well as from Europe. Among others, Germany, Sweden, Italy, Greece and Switzerland provide induction programs, but they vary in terms of assessment and resources, for instance, concerning the time given for professional conversation and the remuneration of mentors (Huber, 2010). Countries with little teaching practice during pre-service training, such as Great Britain, France and Italy, add compulsory induction to in-service training. Conversely, Switzerland aims for a high amount of pre-service and in-service training (Blömeke \& Paine, 2009). Models also differ in matters of definition and training concerning the mentors. Paine and Schwille observe that various words and their respective connotations are used to name the mentor in different countries:

“The words used in Shanghai - 'guiding teacher', 'old teacher', or 'master' - are associated with traditional culture and show that in some sense the new teacher is a 'disciple' of the master. In France, mentors are called 'pedagogic advisors', a title that communicates the focus of their work, while in New Zealand, they are 'advice and guidance advisors', department heads, or 'buddy' teachers, which suggest mentoring roles of a different sort" (Paine \& Schwille, 2010, p. 38).

This emphasizes the manifold cultural interpretations of the term and the decisions, which have to be made in order to establish mentoring in schools. Moreover, costs and assessment come into play. Exemplarily, concepts from Great Britain and Switzerland are described in short below.

In Great Britain, newly qualified teachers (NQT) are obligated to participate in an induction program, which is organized by the National College for Teaching and Leadership, a part of the Department for Education (DfE). New teachers can only apply for induction after having obtained qualified teacher status (QTS) in their initial teacher training (ITT). According to the Department of Education, the one-year induction focuses on personal, professional development as well as assessment concerning the Teachers' Standards (DfE, 2013).

Induction tutors support new teachers. They conduct progress reviews and formal conversations, too. Guidelines clearly define the different roles in the process and the corresponding tasks: 
"The induction tutor (or the headteacher if carrying out this role) should:

- provide, or co-ordinate, guidance and effective support including coaching and mentoring for the NQT's professional development (with the appropriate body when necessary);

- carry out regular progress reviews throughout the induction period;

- undertake three formal assessment meetings during the total induction period co-ordinating input from other colleagues as appropriate (normally three termly, or pro rata for part-time staff);

- inform the NQT during the assessment meeting the judgements to be recorded in the formal assessment record and invite NQTs to add their comments;

- ensure that the NQT's teaching is observed and feedback provided;

- ensure NQTs are aware of how, both within and outside the institution, they can raise any concerns about their induction programme or their personal progress; and

- take prompt, appropriate action if an NQT appears to be having difficulties" (DfE, 2013, p. 31).

These requirements merely refer to organization, co-operation, monitoring and assessing, but they do not address other aspects of expertise a mentor needs. For that reason, different boroughs and counties have developed more specific profiles (The Royal Borough of Kensington and Chelsea, Hammersmith \& Fulham, 2013) referring to qualities, such as interest in the role and in another person, communicative skills, an encouraging and fostering attitude, confidence in teaching, experience and problem-solving strategies.

The induction models in Switzerland deal with other preconditions than the concept above; pre-service training already contains teaching practice. As Huber (2013) points out, local mentors support new teachers in the St. Gallen and Rorschach area. These mentors have been trained at regional university colleges of teacher education. They help new teachers in pedagogical and subject matters, in becoming acquainted with school administration and regulations as well as being into contact with authorities. Regional mentors work with study groups consisting of six to eight new teachers. The model clearly describes mentors' tasks and lists the necessary competencies regarding curricular and pedagogical knowledge as well as organizational and social skills (Benz et al., 2005). Here, mentors do not assess the new teachers. This is a very interesting point to discuss, with regards to comparing European models: some countries do not grade their new teachers at all in mentoring, allowing personal and professional development without grading, whereas other literally standardize the concept, which intends to foster reflection and introspection. Such 
decisions are accompanied by cultural interpretations of models like mentoring as such, as well as by matters of educational policy and, consequently, institutional demands.

With regard to the upcoming new teacher-training program in Austria, several projects concerning induction and mentoring have been launched. At present, the University College of Teacher Education Styria is conducting a three-year master's program in mentoring in co-operation with the Catholic University College for Education Graz, the University College of Teacher Education Burgenland and the Karl-Franzens-University Graz. The attendees will act as facilitators for mentors as soon as the new teacher training curriculum comes into effect. Additionally, a research project with a focus on mentoring new primary school teachers is being undertaken. The following remarks refer to the latter project, which, on the one hand, clearly shows references to developments in other European countries, but on the other, clearly emphasizes the need for local variety and refrains from overly restrictive standards.

\section{Developing a regional project}

From 2012 to 2014, the project Supporting New Teachers at the Beginning of their Careers in primary schools is organized by the University College of Teacher Education Styria and strongly supported by the local supervisory school board. The undertaking is situated in the Styrian districts of Leoben and Bruck-Mürzzuschlag.

This region has very distinctive geographical features, with only a few densely populated industrial towns and remote, scarcely inhabited alpine areas. Consequently, employment and schooling are among the significant challenges the population faces. Due to a reduced number of pupils, many isolated schools are in constant danger of being closed down or merged, which also means that only a few teachers are employed. Moreover, it is difficult to hire teachers for these rural schools, because many young people prefer to live in more urban areas. In the centres, however, big classes with considerable heterogeneity are always challenges for teachers. The impending retirement of many teachers is another fact that contributes to the current situation.

In each of the two project years, about 40 new teachers started their careers. In order to meet the needs of the prevailing situation, a program to support new teachers was developed. However, it has to be mentioned that the pilot scheme at that time neither included any reduction of teaching time for participants nor remuneration of mentors. Mentors at the local schools were appointed by the principals; in-service training for new teachers with regards 
to curricular, pedagogical and organizational knowledge, social and personal skills was provided by the University College of Teacher Education Styria. Mentors and principals were offered in-service training about mentors' roles and duties, inducing learning conversations and giving critical acclaim. Additionally, there was a particular focus on reviewing previous actions and changes in the teaching profession. Table 1 contains an overview of the project's training facilities.

Table 1. In-service training facilities

\begin{tabular}{lll}
\hline New Teachers & Mentors & Principals \\
\hline $\begin{array}{l}\text { professional role and } \\
\text { identity }\end{array}$ & $\begin{array}{l}\text { mentors' roles and respon- } \\
\text { sibilities }\end{array}$ & $\begin{array}{l}\text { reflecting and defining a } \\
\text { mentor's role }\end{array}$ \\
\hline $\begin{array}{l}\text { classroom management and } \\
\text { parent-teacher meetings }\end{array}$ & $\begin{array}{l}\text { the basic concept of } \\
\text { educative mentoring }\end{array}$ & $\begin{array}{l}\text { inducing professional con- } \\
\text { versation }\end{array}$ \\
\hline $\begin{array}{l}\text { individualization in teaching } \\
\text { and assessment }\end{array}$ & $\begin{array}{l}\text { changes and innovation in } \\
\text { professional development }\end{array}$ & $\begin{array}{l}\text { observing and providing } \\
\text { feedback }\end{array}$ \\
\hline
\end{tabular}

Monitoring research accompanies the project during the two-year period. The primary objective is to explore factors of successful mentoring on various levels concerning personal, structural and systemic development. Moreover, the concept of mentoring is analysed in terms of implications on school development and human resources. Consequently, the following research questions, which are based on studies analyzing new teachers' needs at the beginning of their professional careers (Hericks, 2006; Cameron, 2007; He, 2009, and Keller-Schneider, 2010) are the focus of interest:

- Which factors help to establish successful mentoring?

- How can mentoring help build professionalism in new teachers?

- How does specific in-service training facilitate new teachers' starts in professional life?

- Which roles do social and digital networks play with regard to the challenges of new teachers' professionalism?

In order to answer these questions, a mixed-methods approach is applied. The research contains written surveys with new teachers and mentors at the beginning and the end of the school year (October and June). Each participant uses the same anonymous code for both questionnaires. The questions in the first survey are kept open-ended and focus on the participants' expectations about mentoring, as can be seen in Table 2. 
Table 2. Questions from the written survey in October

\begin{tabular}{c|c}
\hline \multicolumn{2}{c}{$\begin{array}{c}\text { Written Survey at the Beginning of the School Year } \\
\text { (October 2012; sample questions) }\end{array}$} \\
$\begin{array}{c}\text { New Teachers } \\
\text { (21 questions) }\end{array}$ & \multicolumn{1}{c}{$\begin{array}{c}\text { Mentors } \\
\text { (19 questions) }\end{array}$} \\
\hline $\begin{array}{l}\text { Which hopes, wishes and concerns are there } \\
\text { regarding your first year at school? }\end{array}$ & $\begin{array}{l}\text { What are your reasons for participating as a } \\
\text { mentor in this project? }\end{array}$ \\
\hline $\begin{array}{l}\text { In which fields of the profession do you wish } \\
\text { to draw upon your mentor's experience? }\end{array}$ & $\begin{array}{l}\text { In which fields of the profession do you see } \\
\text { exceptional challenges for new teachers? }\end{array}$ \\
\hline \multicolumn{2}{c}{ What makes a good mentor? / What makes an ideal mentoring relationship? } \\
\hline \multicolumn{2}{c}{ organize mentoring? } \\
\hline
\end{tabular}

The second questionnaire contains open-ended question formats referring to the target group's experiences during the project, as well as quantifiable multiple-choice formats. The latter aim at evaluating the in-service training facilities, which are additionally offered in the course of the mentoring project. Table 3 displays a few samples from this written survey.

In order to investigate the research questions concerning factors for successful mentoring as well as how it can contribute to building professionalism in new teachers, group discussions are conducted. Based on Bohnsack, Marotzki and Meuser's approach (2003), these discussions with new teachers, mentors and principals in March allow for oral feedback pertaining to topics such as pre-service and in-service training as well as experiences resulting from the evolving mentoring relationships.

Additionally, recurring expert interviews are conducted, one at a time, in three different schools each year, with the new teacher, the mentor and the principal. On the one hand, these talks aim at finding out how regional differences influence factors of successful mentoring; on the other, they allow a close-up of several mentoring situations, which illustrates the process of professional development in new teachers. Accordingly, questions in these interviews ask about the local school's specific situation, the perception and assessment of the mentoring concept among school staff and project participants as well as in-depth descriptions of the respective mentor and new teacher's co-operation. Inquiries also investigate experiences with in-service training offered in the course of the project and the establishment of peer networks.

To summarise, the questionnaires aim at showing the participant groups' general attitudes, expectations and evaluations, whereas the group discussions serve as feedback options about the running project. The semi-structured 
interviews provide insights into the manifold and complex processes that occur during mentoring.

Table 3. Items from the written survey in June

\begin{tabular}{|c|c|c|c|c|c|}
\hline \multicolumn{6}{|c|}{$\begin{array}{l}\text { Written Survey at the End of the School Year } \\
\text { (June 2013; sample questions) }\end{array}$} \\
\hline \multicolumn{2}{|l|}{$\begin{array}{l}\text { New Teachers } \\
\text { (20 questions/items) }\end{array}$} & \multicolumn{4}{|c|}{$\begin{array}{l}\text { Mentors } \\
\text { (19 questions/items) }\end{array}$} \\
\hline \multicolumn{2}{|c|}{$\begin{array}{l}\text { In which fields of your profession did you } \\
\text { succeed in your first year? }\end{array}$} & \multicolumn{4}{|c|}{$\begin{array}{l}\text { Being a mentor, in which fields did you } \\
\text { gather new experience? }\end{array}$} \\
\hline \multicolumn{2}{|c|}{$\begin{array}{l}\text { Which areas were not covered in pre-service } \\
\text { training? }\end{array}$} & \multicolumn{4}{|c|}{$\begin{array}{l}\text { Would you like to continue to work as a } \\
\text { mentor in the future? Why (not)? }\end{array}$} \\
\hline \multicolumn{6}{|c|}{$\begin{array}{l}\text { Which challenging situations occurred during the year? / Which topics were discussed in } \\
\text { mentoring? }\end{array}$} \\
\hline \multicolumn{6}{|c|}{ Please describe your mentoring relationship! } \\
\hline \multicolumn{6}{|c|}{ Which surrounding conditions were encouraging? Which ones were discouraging? } \\
\hline \multicolumn{6}{|c|}{ How was mentoring dealt with at your school? Among colleagues? By the principal? } \\
\hline \multicolumn{6}{|c|}{11 statements concerning mentoring for respective group (Likert-scale; example): } \\
\hline & $\begin{array}{l}\text { strongly } \\
\text { agree }\end{array}$ & agree & disagree & $\begin{array}{l}\text { strongly } \\
\text { disagree }\end{array}$ & commentary \\
\hline \multicolumn{6}{|l|}{$\begin{array}{l}\text { A mentor eases the start in a } \\
\text { new profession. }\end{array}$} \\
\hline $\begin{array}{l}\text { I consider the relationship } \\
\text { with my mentor/mentee } \\
\text { successful. }\end{array}$ & & & & & \\
\hline
\end{tabular}

How much mentoring time was invested per week?

$\square 15$ minutes $\square 30$ minutes $\square$ hour $\square 2$ hours $\square$ other:

Evaluation of in-service training facilities for respective group

( 9 seminars for new teachers to choose from, 4 for mentors; example):

\begin{tabular}{|l|l|l|l|l|l|}
\hline & $\begin{array}{c}\text { highly } \\
\text { satisfied }\end{array}$ & satisfied & $\begin{array}{c}\text { not } \\
\text { satisfied }\end{array}$ & $\begin{array}{c}\text { not at all } \\
\text { satisfied }\end{array}$ & $\begin{array}{c}\text { did not } \\
\text { participate }\end{array}$ \\
\hline $\begin{array}{l}\text { Mentoring Basics } \\
\text { (October) }\end{array}$ & & & & & \\
\hline
\end{tabular}

Did you use the moodle online network? Why (not)?

Did you network with other new teachers/mentors? Why (not)?

The qualitative analysis entailed in the project is rooted in the reconstructive tradition; the recorded data was transcribed and categorized by adapting Mayring's content analysis (2010) as well as Gläser and Laudel's guidelines (2010) for expert interviews. Categories were introduced by an inductive approach using an open coding system. 
In the project area, all the primary schools with new teachers participated: 42 teachers, 35 mentors and 32 principals. The heads of schools were responsible for nominating the mentors. The age of the mentors varied between 24 and 60 years of age with 3 to 30 years of work experience. All mentors and new teachers were given the two questionnaires (paper format) and asked to complete them. However, the response rates in the written surveys in the first year of the project varied considerably, as can be seen in Table 4.

Table 4. Response rates in the written surveys

\begin{tabular}{lll}
\hline & New Teachers & Mentors \\
\hline October 2012 & 31 out of 42 & 26 out of 35 \\
June 2013 & 25 out of 38 & 15 out of 31 \\
\hline
\end{tabular}

Differences in the total number of participants in the surveys in June result from changes concerning employment status, number of staff ill or on maternity leave.

The following chapter will focus on the mentors, depicting interesting results from the research mainly drawn from the data analysis of the two written surveys.

\section{On stage: experiences from the project year 2012/2013}

This chapter deals with findings from the research referring to the mentor's role. At the beginning of the project year, none of the participants had been officially placed in such a position before and therefore could neither rely on experience nor specific training with theoretical knowledge about the concept. Due to the previous lack of a nationwide program including all types of schools, mentors in this project learned about competence concerning the mentoring project and how to put it into practice simultaneously. In this respect, the focus of interest here is on how the new mentors in this project evaluate the concept based on their experiences of the ongoing school year.

Participants' expectations in October 2012 already showed how much was expected from the mentors in this particular situation - by themselves and by the new teachers. Experiences after a year of mentoring are reported and analysed below. Finally, conclusions for the second project year and recommendations for induction in the new Austrian teacher training are drawn. 


\section{The wish list}

Early in the project, in the first written survey in October 2012, new teachers and mentors were asked about their beliefs and expectations concerning the project, and, especially the mentor's role. Answering to the question what makes a good mentor, new teachers and mentors conceptualize a similar picture, which is illustrated in Table 5 .

Table 5. What makes a good mentor?

\begin{tabular}{r|l}
\hline \multicolumn{1}{c}{ New Teachers } & \multicolumn{1}{c}{ Mentors } \\
\hline \multicolumn{2}{c}{...confident, competent, well-organized } \\
\hline \multicolumn{1}{c}{....being patient and taking time } \\
\hline \multicolumn{1}{c}{...offering respectful towards the new teacher } \\
\hline ...being a mentor voluntarily & ...open to questions \\
\hline ...listening and keeping conversations & ...open-minded, interested, motivated \\
\hline confidential & ...helping with words and deeds at all times \\
\hline ....attending in-service training & $\begin{array}{l}\text {...cooperative and friendly, on a level playing } \\
\text { field }\end{array}$ \\
\hline ...likes being a teacher & ...giving appreciative feedback \\
\hline
\end{tabular}

Interestingly, in the first four features mentioned in Table 5 , new teachers and mentors are in total agreement. These characteristics refer to curricular and pedagogical knowledge, which are accompanied by a strong focus on establishing a working relationship based on mutual respect. This first survey emphasized that, in addition to relationship based on trust, having enough time for professional conversation is one of the most important factors. Moreover, another emphasis, with a thoroughly demanding implication, becomes clear: mentors shall always be available in case they are needed.

When it comes to describing the ideal relationship between mentor and new teacher, the mentors point out that their new colleagues have to feel comfortable with them, which can only be achieved in an atmosphere based on mutual trust and with an open respectful way of communication, as had been stressed earlier by Bobek (2002). Moreover, there has to be a clear understanding that positive reinforcement, fostering individual development, and mutual learning are among the goals that resemble research findings by Cooper and Stewart (2009). Additionally, it has to be emphasized that support is offered without obtrusion. The new teachers want to talk freely to their mentors, 
without any fears. They appreciate honest and critical feedback on a level playing field, sharing experiences, swapping material and regular meetings. From the new teachers' point of view, a combination of quick, situation-related queries and longer professional reflective talks is most effective. Again, the factor of time comes into play, especially regarding the mentors' availability.

Interestingly, 21 out of 26 mentors did not hesitate to accept their principals' request to take up this new role. For many, it went without saying that new colleagues have to be supported; some mentors referred to their own almost traumatic career starts as a reason that they agreed to working in this position. Many experienced colleagues were surprised by the high number of new teachers and saw the need and value of the mentoring concept. Moreover, they regarded the model as a means for enhanced school quality and development, for example through teamwork.

\section{The mentoring experience}

After a year of mentoring, a second written survey was conducted in June 2013. Results from the annual group discussions and the expert interviews with new teachers, mentors and principals in three schools were supported by this inquiry. Further depictions in this paper focus on the mentors to emphasize the importance and challenges of their duties.

Generally, the mentors described their experiences as positive, manifold and interesting. They referred to their own role in a responsible position with a role model function and highlighted the strong feeling of commitment, which accompanied the official appointment to the position. It added to their previous profile as a teacher and allowed new insight into collegial co-operation. In this respect, the mentors reported increased skills in communication and observation, perception and reflection. It proved to be essential to acknowledge the new teachers as equals by trusting them. The mentors observed that, depending on the new teachers' personalities, their task was to be there, willing to help and interested in the new colleagues' progress in the first place. Listening sensitively and actively and providing experience and guidance to individual solutions were mentioned as means of professional communication. Reflecting on their own beliefs turned out to be a key to new learning processes in mentors; many had forgotten about actions performed in their daily routines that had become unconscious routines. In addition, the mentors drew attention to the difficult balance between supporting new teachers and not forcing their advice on them. Moreover, it was evident that the mentors felt obligated to confront new teachers with positive as well as constructive critical feedback, which definitely exceeded the usually existing supportive attitude among colleagues, which many 
teachers had mentioned in the project year's first survey.

During that year, mentors dealt with various areas that were demanding for new teachers. As studies (Lipowski, 2003; Martinuzzi, 2007; Keller-Schneider, 2010) have already confirmed, the new teachers consulted their mentors concerning:

- curricular knowledge about assessment, annual planning, education standards, individualization and differentiation;

- $\quad$ pedagogical knowledge about pupils displaying behavioural problems, implementing codes of conduct, mixed-level classes and classroom management;

- $\quad$ organizational knowledge about local school administration and school laws;

- $\quad$ social skills for parent-teacher meetings, relationships with colleagues, principals and superintendents, and

- $\quad$ personal skills for time management, work-life balance and coping with individual expectations.

More than half of the mentors in the survey described various challenging situations during the process. They referred mainly to problems concerning time in various ways. Due to set timetables, attendance at school was often impossible: Austrian primary school teachers are usually entirely responsible for their class including hall monitoring. As a result of the reduction of total teaching time, many schools had not set specific timeframes for professional conversation, so mentors and new teachers had to organize their meetings individually.

Moreover, the specific regional situation came into play. First many new teachers and mentors in the area were commuters, so time management required considerable flexibility on both sides. Next, up to five new teachers started their first year at the same school. As pointed out earlier, because of the size of many local schools, there were not enough mentors in such cases. Then, some very small schools ended up with the principals as the only experienced teacher plus one or two new teachers. Under these circumstances, the heads of schools served as mentors, which caused other difficulties, for example with hierarchy in case there were any conflicts of opinion. This underlines the importance of bearing in mind reflective questions about how mentoring is defined and carried out in various countries and their particular regions.

In the course of the project, it was seen that various forms of time management were established. The written survey in June 2013, as well as the expert interviews, proved that once a particular structure for meetings had been set, 
it was kept throughout the year; for the vast majority, that meant a total of one to two hours a week. Many included their conversations in joint lessons for planning, especially when mentor and new teacher worked on the same class level. This appeared to be the most appreciated combination, because (as a matter of course) the mentoring-team was able to co-operate content-wise as well as in areas such as individualization, grading or classroom organization. In the reflection, some mentors who had offered a lot of time for spontaneous conversation and, in some cases, had more than one new teacher to attend to, contemplated another solution for the following year. They would try to arrange mentoring at set times to avoid overwork.

Here, the important role of school advisory boards and principals as facilitators of induction programs with mentoring becomes evident. Not only do the new teachers have to be cared for, but so do the mentors. Even though 25 out of 31 mentors report their principals' support on a personal level, about 15 of them observed that the concept was not selected as a central theme in conferences at all. Some even experienced alarming reactions from their colleagues. Many did not respond to the project at all, pitied the mentors because of the extra workload, or in single cases, even accused the mentors of acting like "the queen bee" by taking on this position. Therefore, it is clear that professional development must not only focus on support for new teachers in order to avoid attrition at the beginning of their careers, but has to be a recurring topic and constant basing point for lifelong learning in teachers.

\section{Mentoring in mind}

Learning cannot be finished at any time. Correspondingly, Gardner's concept of five minds for the future (2009), which has already been referred to, opens developmental fields for the individual. Regarding the concept knowledge of new mentors, this means examining their own beliefs and attitudes as well as facilitating the new teachers' growth, both on personal and professional levels. Accordingly, the following set of features for mentors always requires permanent reflection and must not be regarded as a list of tasks that has to be fulfilled.

With this intention and based upon the conclusions from the research results above, a mentor's duties can be split into areas of individual experience and professional development as well as content-based tasks. This, in combination with Gardner's five minds, can be used to illustrate the concept, which is summarized in Table 6. 
Table 6. Mentors' fields of development and tasks

\begin{tabular}{ll}
\hline $\begin{array}{l}\text { Areas of Experience and Professional } \\
\text { Development }\end{array}$ & Content-Based Tasks \\
\hline Disciplinary Mind & \\
\hline $\begin{array}{l}\text { various years of teaching experience; } \\
\text { enthusiastic about pupils and teaching }\end{array}$ & $\begin{array}{l}\text { supporting new teachers in curricular, peda- } \\
\text { gogical, organizational, social and personal } \\
\text { matters }\end{array}$ \\
\hline $\begin{array}{l}\text { Synthesizing Mind } \\
\text { interest in school development }\end{array}$ & $\begin{array}{l}\text { introducing and integrating new teachers } \\
\text { quickly }\end{array}$ \\
\hline $\begin{array}{l}\text { Creating Mind } \\
\text { willingness to try out new ideas and to } \\
\text { participate in in-service training }\end{array}$ & $\begin{array}{l}\text { establishing professional learning teams } \\
\text { with new teachers }\end{array}$ \\
\hline $\begin{array}{l}\text { Respectful Mind } \\
\text { communicative skills for mentoring and } \\
\text { coaching processes }\end{array}$ & $\begin{array}{l}\text { conducting respectful, empowering profes- } \\
\text { sional conversations }\end{array}$ \\
\hline $\begin{array}{l}\text { Ethical Mind } \\
\text { reflection and introspection concerning the } \\
\text { mentor's own work (as a teacher and as a } \\
\text { role model for new teachers) }\end{array}$ & $\begin{array}{l}\text { acting as a mediator (new teacher - princi- } \\
\text { pal, new teacher - teacher colleagues) }\end{array}$ \\
\hline
\end{tabular}

Providing such a profile not only serves as a means for finding enthusiastic mentors, but also offers a guideline for teachers interested in such a role. Moreover, such a model illustrates its requirements, which essentially means being ready for continuous professional learning with responsibility for and partaking in a colleague's initial career phase. It also shows that mentoring must not undermine the new teacher's personal responsibility; on the contrary, the objective is to empower the new teachers to find their individual solutions an approach that strongly relies on Deci and Ryan's "Self-Determination Theory of Motivation" (1993) and Reeve and Jang's research (2006) concerning the support of autonomy in learners.

With this intention, one focus in the second year of the project is on further in-depth observation of the mentor's role, taking into account topics such as mentors' positions among their colleagues, (self-)evaluation for both, mentor and new teacher, and fostering learner autonomy in general.

\section{Conclusion and implications}

Mentoring for new teachers may serve as a supportive and constructive concept in various countries. However, several decisions concerning the level of 
formality, the contents of such programs and the costs have to be kept in mind. Regarding the role of the mentor, further decisions have to be made; for example: Can a mentor who supports a novice also assess that person? Shall the mentor be chosen by the beginner teacher or assigned? Can mentoring and mentor training happen simultaneously? Schwille, Dembélé and Schubert (2007) raise these questions among others in order to emphasize the complexity of the concept and its various applications. In a detailed study, Britton et al. (2003) pointed out that among the five countries they compared there was hardly any consensus on such questions but individual national solutions which reflected the countries' manifold cultural approaches.

Just as mentoring not only emphasizes curricular and pedagogical knowledge but also contributes to the formation of professional beliefs and attitudes, human resources and school development constantly have to focus on continuous individual learning processes. Viewed in this wider context, this adds to a joint dimension and understanding of professional learning in teachers, which is, of course, not only part of mentoring processes but becomes clearly visible in these relationships: co-operation, openness, interest, tolerance, respect and communication are virtues that are goals in teaching pupils or students, but must be especially valid for teachers, too. Educative mentoring evinces a gap in which new relationships can contribute to the growth and creation of new forms of professional learning by forming new communities or, as Niklas Luhmann puts it, "it is only non-knowing systems that can know; or, one can only see because one cannot see" (Luhmann, 2002, p. 132).

However, individual, professional and systemic development are only some of the reasons mentoring proves to be a valuable support at a teacher's career start in various countries; the concept also contributes to augmented communication among teachers. What this discussion about experiences with mentoring also shows is a way to bridge the generation gap and enable the transfer of knowledge within schools. Establishing mentoring officially also means accepting an obligation for the employees' development. Here, guidance ideally refers to open-mindedness based on self-motivation, bearing in mind principles, such as Gardner's (2009) and Deci and Ryan's (1993), to increase new teachers' and mentors' awareness towards meeting future challenges.

In contrast to the wider perspective presented above, concepts like mentoring must also be considered on a regional, or even local level depending on the very circumstances. Therefore, it is necessary to keep an eye on cultural contexts and fit when transferring one model to another European nation. Values and traditions of assessment or the definition of good teaching vary considerably, and the acceptance of such models differs accordingly. This 
complex bridge between European and national concepts requires the respect of individual countries' needs.

Regarding the project described above, one goal is to investigate which factors help to establish successful mentoring; in this case, focusing on the mentor. One of these is certainly the suitability of the mentor for the individual. New teachers' personal needs to enable individual and professional development must be met as well as regional needs, when, for example, schools are very small and not enough mentors are available. Establishing professional learning communities by employing regional mentors is one adequate way to deal with structural differences. Moreover, it adds to the mentoring concept of one mentor and one to two new teachers at the local school by providing regular communication apart from the consolidation of (new) hierarchical structures.

It was indicated in the current research results that the following factors can be viewed as necessary components to make mentoring work: the principals' willingness to establish the program and to support the mentors' activities, the mentors' official appointment and voluntary participation, sufficient time slots, and a relationship based on mutual trust between mentor and mentee. The latter issue reflects the new teachers' need for emotional support (Hargreaves \& Fullan, 2000; Zachary, 2000), although there is a strong focus on reciprocal learning as referred to by Cooper and Stewart (2009). At the same time, new teachers have high expectations concerning the availability of mentors and the time they are willing to spend with their mentees. This finding is important for the mentors to prevent them from overstraining.

Taking mentors' qualities into account, it can be reiterated that they not only have to have excellent curricular, pedagogical and organizational knowledge, but also social and communicative skills to lead effective conversations and foster new teachers' professional development, as research evidence has already suggested (McDonald \& Flint, 2011). Challenging in this respect is the fact that there is no compulsory training for mentors in Austria thus far, and projects take place only in test settings in which the mentors are not offered any remuneration or lesson reduction for this professional work. However, the mentors' great willingness to learn about the concept and their positive reactions to the pilot project show the value they allot to this means of professional development for new teachers and themselves.

In order to arrive at a general conclusion, it can be stated that - given the chance - new teachers and mentors mostly appreciate working in professional teams to experience the joy and benefit of co-operation and reflective talk, because it not only leads to investigating their own but also their pupils' potentials in order to set the stage for further mindful learning. Therefore, it is high time 
for school authorities to acknowledge that professional mentoring needs set times for reflection and to establish high quality in-service training facilities for current and future mentors.

\section{Acknowledgements}

The author gives sincere thanks to the research team at the University College of Teacher Education Styria: Andrea Völkl, Angelika Kornberger, Silvia Kopp-Sixt and project leader Andrea Holzinger.

\section{References}

Benz, A., Birri, C., Lehner, M., \& Vogt, F. (2005). Konzept der Berufseinführung für Lehrpersonen der Volksschule im Kanton St. Gallen. Retrieved 31.1.2013 fromhttp://edudoc.ch/record/3846/files/ Berufseinführung_Konzept_Info_Schulträger_junio6.pdf

Bobek, B. (2002). Teacher resilience: A key to career longevity. The Clearing House, 75(4), 202-205. Bohnsack, R., Marotzki, W., \& Meuser, M. (Eds.) (2003). Hauptbegriffe Qualitativer Sozialforschung. Opladen: Leske+Budrich.

Blömeke, S., \& Paine, L. (2009). Berufseinstiegs-Programme für Lehrkräfte im internationalen Vergleich. Journal für LehrerInnenbildung, 9(3), 18-25.

Britton, E., Paine, L., Pimm, D., \& Raizen, S. (2003). Comprehensive teacher induction. Dordrecht: Kluwer Academic Publishers.

Cameron, M. (2007). Learning to teach: A literature review of induction theory and practice.

Wellington: New Zealand Council for Educational Research.

Cooper, M., \& Stewart, J. (2009). 'Learning together, shaping tomorrow': New teachers try new ways. Research in Comparative and International Education, 4(1), 111-122.

Deci, E. L., \& Ryan, R. M. (1993). Die Selbstbestimmungstheorie der Motivation und ihre Bedeutung für die Pädagogik. Zeitschrift für Pädagogik, 39(2), 223-238.

Department for Education. (2013). Statutory guidance on induction for newly qualified teachers (England). For appropriate bodies, headteachers, school staff and governing bodies. Revised June 2013. Retrieved 29.12.2013 from http://education.staffordshire.gov.uk/NR/rdonlyres/78954769-535E493A-A676-14FE5F769BDD/171548/statutoryguidancerevisedjune2013.pdf

Feiman-Nemser, S. (2001). Helping novices learn to teach: Lessons from an exemplary support teacher. Journal of Teacher Education, 52(1), 17-30.

Feiman-Nemser, S. (2003). What new teachers need to learn. Educational Leadership, 6o(8), 25-29. Fuller, F. F., \& Brown, O. H. (1975). Becoming a teacher. In K. Ryan (Ed.), Teacher Education. $74^{\text {th }}$ Yearbook of the NSSSe. Part II. (pp. 182-185). Chicago: University of Chicago Press. Gardner, H. (2009). Five Minds for the Future. Boston: Harvard Business School Press. Gläser, J., \& Laudel, G. (2010). Experteninterviews und qualitative Inhaltsanalyse. 4. Auflage. 
Wiesbaden:Verlag für Sozialwissenschaften.

Halai, A. (2006). Mentoring in-service teachers: Issues of role-diversity. Teaching and Teacher

Education, 22(6), 700-710.

Hargreaves, A., \& Fullan, M. (2000). Mentoring in the new millennium. Theory into Practice, 39, $50-56$.

Harrison, J. K., Dymoke, S., \& Pell, T. (2006). Mentoring beginning teachers in secondary schools: an analysis of practice. Teaching and Teacher Education, 22, 1055-1067.

He, Y. (2009). Strength-based mentoring in preservice teacher education: A literature review.

Mentoring \& Tutoring: Partnership in Learning, 17(3), 263-275.

Helsper, W. (1996). Antinomien des Lehrerhandelns in modernisierten pädagogischen Kulturen: Paradoxe Verwendungsweisen von Autonomie und Selbstverantwortlichkeit. In A. Combe \& W. Helsper (Eds.), Pädagogische Professionalität: Untersuchungen zum Typus pädagogischen Handelns (pp. 521-569). Frankfurt am Main: Suhrkamp.

Helsper, W. (2012). Antinomien im Lehrerhandeln. Professionelle Antinomien - vermeidbare Verstrickung oder pädagogische Notwendigkeit? Lernende Schule, 15(60), 30-34.

Hericks, U. (2006). Professionalisierung als Entwicklungsaufgabe: Rekonstruktionen zur Berufseingangsphase von Lehrerinnen und Lehrern. Wiesbaden: Verlag für Sozialwissenschaften.

Huber, U. (2010). Der Begleitete Berufseinstieg für PflichtschullehrerInnen in Europa. Frankfurt am Main: Peter Lang Verlag.

Huber, U. (2013). Mentoring im Berufseinstieg. Erziehung \& Unterricht, 163(1-2), 32-39.

Hubermann, M. (1991). Der berufliche Lebenszyklus von Lehrern: Ergebnisse einer empirischen Untersuchung. In E. Terhart (Ed.), Unterrichten als Beruf. Neuere amerikanische und englische Arbeiten zur Berufskultur und Berufsbiographie von Lehrerinnen und Lehrern (pp. 249-267). Köln, Wien: Böhlau.

Ittel, A., \& Raufelder, D. (2009). Mentoring in der Schule: Professionelle Praxis und

Qualitätssicherung. In H. Stöger, A. Ziegler, \& D. Schimke (Eds.), Mentoring: Theoretische

Hintergründe, empirische Befunde und praktische Anwendungen (pp. 207-223). Lengerich: Papst Science Publishers.

Keller-Schneider, M. (2010). Entwicklungsaufgaben im Berufseinstieg von Lehrpersonen. Münster: Waxmann

Langdon, F. J. (2007). Beginning teacher learning and professional development: An analysis of induction programmes. Hamilton: University of Waikato.

Lipowski, F. (2003). Wege von der Hochschule in den Beruf: Eine empirische Studie zum beruflichen Erfolg von Lehramtsabsolventen in der Berufseinstiegsphase. Rieden: Klinkhardt.

Luhmann, N. (2002). The cognitive program of constructivism and a reality that remains unknown.

In W. Rasch (Ed.), Theories of distinction: Redescribing the descriptions of modernity (pp. 128-152).

Stanford, CA: Stanford University Press.

Martinuzzi, S. (2007). Der Berufseinstieg - Unterstützungsmaßnahmen für Lehrerinnen und Lehrer in der Grundschule. Wien: Lit. 
Mayring, P. (2010). Qualitative Inhaltsanalyse. Grundlagen und Techniken. 11. Auflage. Weinheim und Basel: Beltz Verlag.

McDonald, L., \& Flint, A. (2011). Effective Educative Mentoring Skills: A Collaborative Effort. New Zealand Journal of Teachers' Work, 8(1), 33-46.

Meuser, M., \& Nagel, U. (1997). Das ExpertInneninterview - Wissenssoziologische Voraussetzungen und methodische Durchführung. In B. Friebertshäuser \& A. Prengel (Eds.), Handbuch Qualitative Forschungsmethoden in den Erziehungswissenschaften (pp. 481-491). Weinheim, München: BeltzJuventa.

Messner, H., \& Reusser, K. (2000). Die berufliche Entwicklung von Lehrpersonen als lebenslanger Prozess. Beiträge zur Lehrerbildung, 18(2), 157-171.

New Zealand Teachers Council. (2011). Guidelines for Induction and Mentoring and Mentoring Teachers. Retrieved 05.11.2013 from http://www.otago.ac.nz/education/otagoo42474.pdf Norman, P. J., \& Feiman-Nemser, S. (2005). Mind Activity in Teaching and Mentoring. Teaching and Teacher Education, 21(6), 679-697.

Paine, L. W., \& Schwille, J. R. (2010). Teacher Induction in International Contexts. In J. Wang, S. Odell, \& K. T. Clift (Eds.), Past, Present, and Future Research on Teacher Induction. An Anthology for Researchers, Policy Makers, and Practitioners (pp. 31-44). Langham, Maryland: Rowman and Littlefield Education.

Reeve, J., \& Jang, H. (2006). What Teachers Say and Do to Support Students' Autonomy During a Learning Activity. Journal of Educational Psychology, 98(1), 209-218.

Schwille, J., Dembélé, M., \& Schubert, J. (2007). Global perspectives on teacher learning: improving policy and practice. Retrieved 2.8.2014, from http://unesdoc.unesco.org/images/o015/001502/150261e. pdf

The Royal Borough of Kensington and Chelsea, Hammersmith and Fulham. (2013). A guide for induction tutors 2013-2014. Retrieved 29.12.2013 from http://www.rbkc.gov.uk/PDF/A\%2oguide\%2O for\%2oinduction\%2otutors2013-14_100913.pdf Terhart, E. (2001). Lehrberuf und Lehrerausbildung. Forschungsbefunde, Problemanalyse, Reformkonzepte. Weinheim: Beltz.

Wang, J., \& Odell, S. J. (2007). An alternative conception of mentor-novice relationships: Learning to teach in reform-minded ways as a context. Teaching and Teacher Education, 23(4), 473-489. Zachary, L. (2000). The mentor's guide: Facilitating effective learning relationships. San Francisco, CA: Jossey-Bass. 


\section{Biographical note}

KARIN DA RochA, dr., is a lecturer and researcher at the University College of Teacher Education Styria in Graz, Austria, with a Master's in Teaching English as a Foreign Language (TEFL) and German from the University of Vienna and a doctorate in education/lifelong learning from the University of Klagenfurt. She has previously taught English and German in Brazilian and Austrian secondary schools. Her current research interests include induction and mentoring, learner autonomy, critical thinking, visual literacy and teaching literature in EFL. 